\title{
Satisfaction of Patients from the Quality Service of Diagnosis of Health Problem in Public Health Institutions of Nepal
}

\author{
Milan Gurung $^{1} \&$ Dr. Arvind Saraswat ${ }^{2}$ \\ ${ }^{1} \mathrm{PhD}$ Scholar of OPJS University, Churu, Rajasthan, India \\ ${ }^{2}$ Research Supervisor, OPJS University, Churu, Rajasthan, India \\ Corresponding Author \\ Milan Gurung \\ Email: milan90@hotmail.com
}

\begin{abstract}
Health should be the first priority of each people; people can do creative work if s/he is healthy. According to the annual report of the Department of Health Services (DoHS) for fiscal year 2072/73 (2015/2016), the main institutions that delivered basic health services were 104 public hospitals, 303 private hospitals, 202 primary health care centres (PHCCs) and 3,803 health posts. The primary health care services also provided 12,660 primary health care outreach clinic (PHCORC) sites. The health service was affected from the earthquake of April 2015 so the study aims to identify the satisfaction of patient from quality of diagnosis of health problem in public health institutions after earthquake. The study had covered 82 health institutions 45 from Kavre and 37 from Sindhupalchowak district). The statistical result of $t$-test shows that there was significant difference in approach of doctors $(p=.012)$, and counselling of doctors $(p=.043)$ but there was no difference in answering the queries promptly $(p=.187)$, and explanation given for aliment $(p=.180)$. The descriptive data show slight increase in level of satisfaction of patient after earthquake. Still health posts established in rural setting have inadequate human resource basically doctors are not adequate so Government should provide the trained Doctor in rural areas to increase the access of rural people in health services.
\end{abstract}

Keywords: Diagnosis, Health, Patient, Quality service, Satisfaction

\section{Introduction}

On 25th April 2015, a 7.8 Richter scale tremor with a few noteworthy post-quake tremors struck Nepal slaughtering roughly 9,000 individuals and specifically influencing one third of its 26 million people (Ministry of Health and Population, 2015). Stress gathered between the Eurasian and the Indian Plates frequently cause visit earthquakes what's more, there have been a few noteworthy earthquake in Nepal over the previous century in 1934, 1980, 1988 and 2011 (Binns \& Low, 2015). There was great effect in infrastructure and service of health sectors from the 
Nepal Journal of Multidisciplinary Research (NJMR) Volume 2, No. 3
September 2019
ISSN: 2645-8470 (Paper)

ISSN: 2705-4691 (Online)

earthquake. Basically, people from the rural areas had to suffer more because of their limited access on health facilities. Immediate after earthquake, Nepal Government focused on the continuity of health service for the needy people. Many non-governmental organizations had also supported to build the building of health institutions to restore the quality of services.

Regarding the effect of natural disaster in human life, many previous studies had explored different types of effect on daily life activities. There is copious writing on the effect of regular disasters. Especially, the effects on psychological wellness amid and post-catastrophic events including seismic tremors have been well discussed (Petal, 2011). However, there is constrained writing around outcomes of catastrophic events such as surge, and seismic tremor on general health and the health framework. This paper, along these lines, addresses the effect of earthquake on the populace's health and health foundations in Nepal and prescribes potential intercessions and research needs in the post-earthquake time. Catastrophic events including quake can have genuine social and health consequences (Watson, Gayer, \& Connolly, 2007; Noji, 2000) and these outcomes can be extremely unpredictable. The prompt impact is on mortality and dreariness from crumbled structures. The quantity of setbacks from catastrophic events, nonetheless, relies upon the size, its nearness to thickly populated zones, and the degree of fiasco preparedness (Naghii, 2005). By and large, passing coming about from real seismic tremors are immediate because of extreme pulverizing wounds to the head or chest, outside or interior discharge or deferred, the last happen in the prompt consequence because of clean inward breath of crumbled building, lack of hydration, hypothermia, pulverize disorder, wound diseases, or postoperative sepsis (Partridge, Proano, Marcozzi, Garza, Nameth, \& Brinsfield, 2012). A further hazard is flare-up of transmittable maladies after the seismic tremor because of poor sanitation offices and swarmed sheltering (Watson, Gayer, \& Connolly, 2007).

Regarding the effect of earthquake, a study conducted in Patan Hospital, Lalitpur shows that after the 2015 Nepal earthquake, 12,180 patients were found in the crisis division. This was a critical abatement in persistent volume contrasted and the 14,971 patients seen amid that months in 2014. Of those, 5496 patients (4093 pre-debacles and 1433 post-fiasco) had a central protestation or conclusion recorded for investigation. An expansion in cardiovascular and respiratory cases was viewed and in addition an expansion in mental cases (for the most part liquor related) and instances of paleness. There was abatement in the quantity of obstetrics/gynecology, irresistible malady, and harming cases post-tremor (Tembe, Dhakal, Shrestha, \& Mugele, 2018). The World Health Organization (2016) found that malnourished individuals and individuals who are sick or have a frail invulnerable framework are especially helpless when an earthquake happens (World Health Organization, 2016). Brewer and his friends look at the connection between helplessness, limit, and cataclysmic event results. One of his five key markers of helplessness is prosperity, which is dictated by nutritious status and physical and psychological health. Particular variables incorporate the nature of eating routine, access to human services, and level of pressure. He guarantees that these factors are probably going to 
Nepal Journal of Multidisciplinary Research (NJMR) Volume 2, No. 3
September 2019
ISSN: 2645-8470 (Paper)

ISSN: 2705-4691 (Online)

influence the "capacity to oppose the effect of a danger" (p. 5). In this connection, the study aimed to explore the level of satisfaction of patients from diagnosis of health problem in public health institutions of Kavre and Sindhupalchowk districts.

\section{Materials \& Methods}

The study was conducted in Kavre and Sindhupalchowk districts of Nepal, those districts were severely affected from the devastating earthquake of April 2015. It had destroyed the building and infrastructure of health institutions which affected in the regular health services. There were total 164 health facilities in two districts. This study is institutional based study so 50\% institution was selected randomly from both districts. The study selected 45 health facilities from Kavre and 37 health facilities from Sindhupalchowak district. It was the quantitative study so data were collected from the structured questionnaire survey and collected data were analyzed from the statistical software (SPSS v. 20) and result was presented in tabular form.

\section{Results \& Discussion}

After the devastating earthquake on 2015 which had caused loss of nearly 9,000 deaths and thousands more injured. At that time, almost all hospitals of affected districts were occupied by the injured people. There was huge impact on Sindhupalchowk district due to earthquake than other districts. So many organizations and health institutions, organized health relief camps for medical and surgical treatment and follow up activities for the people affected by earthquake. That was immediate health service and might not have quality health service. But health institutions should provide quality service to the beneficiaries. Due to increasing importance of patient experience and interest in comparing people's satisfaction in health system, it is very important to provide quality health service to the patient and people. One of the most important components to know the quality is people's satisfaction on their provided service. Health service provider's: decent treatment, respect, ethics, and professionalism is needed in order to measure their perception (Al-Salaymeh, 2013).

So quality of service is one of the important areas in the health services sector. This can improve the health of beneficiaries as well as build confidence between the health sector and the beneficiaries to insure the rights and satisfaction of users of the health service (Rocha Rodríguez MR, 2017). So, in providing health care facilities and treatment, it is important to know the satisfaction of the beneficiaries so that it will help to improve their limitation. There is no better way to know about quality service of health care other than knowing from beneficiaries.

\section{Diagnosing}

Diagnosis is an identification of the nature of an illness through examination of symptoms or medical equipment. It is very important stage to determining disease or illness. It helps to prevent from the possible future problem or difficult situation. People in rural areas often have problem in diagnosis of disease because they go to the shaman (Jhakri) for treating their illness. This causes the problem for the patient because they hesitate to go in hospital and they are too far 
Nepal Journal of Multidisciplinary Research (NJMR) Volume 2, No. 3

September 2019

ISSN: 2645-8470 (Paper)

ISSN: 2705-4691 (Online)

too. Nepalese people believe in superstition. Almost every people in village blame others if they have any problem. This type of superstition has caused from getting possible care and prevention. But with improvement in technology, it has become easy to diagnose than before. Doctor can now look the symptoms and go to medical devices to confirm the diseases and only they give prescription.

In this case study, beneficiaries were asked what type of problem they faced in diagnosing disease after the earthquake. They were also asked about their satisfaction on improvements in diagnosis of the diseases after the earthquake. Table 1 shows that Kavre institutions have decreased in answering the queries promptly from $27.9 \%$ to $20.5 \%$. But in Sindhupalchowk, there was increased dissatisfaction level in answering the queries promptly from $21.6 \%$ to $32.4 \%$.

Table 1: Diagnosing

\begin{tabular}{|c|c|c|c|c|c|c|c|c|c|c|}
\hline & \multicolumn{2}{|l|}{ Before } & \multirow[b]{2}{*}{ Total } & \multicolumn{2}{|l|}{ After } & \multirow[b]{2}{*}{ Total } & \multirow{2}{*}{$\mathrm{T}$} & \multirow{2}{*}{$\mathrm{df}$} & \multirow{2}{*}{$\begin{array}{l}\text { Sig. (2- } \\
\text { tailed) }\end{array}$} \\
\hline & & $\sigma>-$ & $2 \pi$ & & $\sigma>-1$ & $2 \quad \pi$ & & & & \\
\hline \multirow{5}{*}{$\begin{array}{l}\text { Answering the } \\
\text { Queries } \\
\text { promptly }\end{array}$} & $\begin{array}{l}\text { Highly } \\
\text { Dissatisfied }\end{array}$ & $27.9 \%$ & $21.6 \%$ & $25.0 \%$ & $20.5 \%$ & $32.4 \%$ & $25.9 \%$ & \multirow{5}{*}{$-\overline{1.331}$} & \multirow{5}{*}{79} & \multirow{5}{*}{.187} \\
\hline & Dissatisfied & & $10.8 \%$ & $5.0 \%$ & & $5.4 \%$ & $2.5 \%$ & & & \\
\hline & Neutral & $16.3 \%$ & $18.9 \%$ & $17.5 \%$ & $9.1 \%$ & $8.1 \%$ & $8.6 \%$ & & & \\
\hline & Satisfied & $48.8 \%$ & $48.6 \%$ & $48.8 \%$ & $63.6 \%$ & $54.1 \%$ & $59.3 \%$ & & & \\
\hline & $\begin{array}{l}\text { Highly } \\
\text { Satisfied }\end{array}$ & $7.0 \%$ & & $3.8 \%$ & $6.8 \%$ & & $3.7 \%$ & & & \\
\hline \multirow[t]{5}{*}{$\begin{array}{l}\text { Counselling by } \\
\text { the doctors }\end{array}$} & $\begin{array}{l}\text { Highly } \\
\text { Dissatisfied }\end{array}$ & $6.8 \%$ & $21.6 \%$ & $13.6 \%$ & $6.8 \%$ & $17.1 \%$ & $11.4 \%$ & \multirow{5}{*}{$\begin{array}{l}- \\
2.058\end{array}$} & \multirow{5}{*}{78} & \multirow{5}{*}{.043} \\
\hline & Dissatisfied & $4.5 \%$ & $13.5 \%$ & $8.6 \%$ & & $8.6 \%$ & $3.8 \%$ & & & \\
\hline & Neutral & $20.5 \%$ & $8.1 \%$ & $14.8 \%$ & $15.9 \%$ & $5.7 \%$ & $11.4 \%$ & & & \\
\hline & Satisfied & $54.5 \%$ & $56.8 \%$ & $55.6 \%$ & $65.9 \%$ & $65.7 \%$ & $65.8 \%$ & & & \\
\hline & $\begin{array}{l}\text { Highly } \\
\text { Satisfied }\end{array}$ & $13.6 \%$ & & $7.4 \%$ & $11.4 \%$ & $2.9 \%$ & $7.6 \%$ & & & \\
\hline \multirow{5}{*}{$\begin{array}{l}\text { Explanation } \\
\text { given for } \\
\text { aliment }\end{array}$} & $\begin{array}{l}\text { Highly } \\
\text { Dissatisfied }\end{array}$ & $2.4 \%$ & & $1.4 \%$ & & & & \multirow{5}{*}{$\overline{1.356}$} & \multirow{5}{*}{63} & \multirow{5}{*}{.180} \\
\hline & Dissatisfied & $2.4 \%$ & & $1.4 \%$ & $5.0 \%$ & & $3.1 \%$ & & & \\
\hline & Neutral & $22.0 \%$ & $34.5 \%$ & $27.1 \%$ & $20.0 \%$ & $32.0 \%$ & $24.6 \%$ & & & \\
\hline & Satisfied & $65.9 \%$ & $65.5 \%$ & $65.7 \%$ & $62.5 \%$ & $64.0 \%$ & $63.1 \%$ & & & \\
\hline & $\begin{array}{l}\text { Highly } \\
\text { Satisfied }\end{array}$ & $7.3 \%$ & & $4.3 \%$ & $12.5 \%$ & $4.0 \%$ & $9.2 \%$ & & & \\
\hline \multirow[t]{5}{*}{$\begin{array}{l}\text { Approach of } \\
\text { the doctors }\end{array}$} & $\begin{array}{l}\text { Highly } \\
\text { Dissatisfied }\end{array}$ & $2.5 \%$ & $10.3 \%$ & $5.8 \%$ & & $8.0 \%$ & $3.2 \%$ & \multirow{5}{*}{$-\overline{2.588}$} & \multirow{5}{*}{60} & \multirow{5}{*}{.012} \\
\hline & Dissatisfied & & $3.4 \%$ & $1.4 \%$ & $5.4 \%$ & & $3.2 \%$ & & & \\
\hline & Neutral & $7.5 \%$ & $10.3 \%$ & $8.7 \%$ & $5.4 \%$ & $12.0 \%$ & $8.1 \%$ & & & \\
\hline & Satisfied & $72.5 \%$ & $75.9 \%$ & $73.9 \%$ & $40.5 \%$ & $76.0 \%$ & $54.8 \%$ & & & \\
\hline & $\begin{array}{l}\text { Highly } \\
\text { Satisfied }\end{array}$ & $17.5 \%$ & & $10.1 \%$ & $48.6 \%$ & $4.0 \%$ & $30.6 \%$ & & & \\
\hline
\end{tabular}

Source: Field Survey, 2019 
We can interpret from the table that after earthquake, in Kavre district there was increased in satisfaction level of beneficiaries in every aspect. On the other hand, in Sindhupalchowk district there was decreased in satisfaction in explanation of aliment, approach of the doctors in diagnosis of the diseases. The statistical p-value of answering the queries promptly (0.187), explanation given for aliment $(0.180)$ both are more than .05 significant level, however, the $\mathrm{p}$ values of counselling by the doctors $(0.043)$, and approach of the doctors $(0.012)$ show that there was significant difference in the services before and after earthquake 2015. Satisfaction level of beneficiaries was not increased because there was no improvement in the services after earthquake. After earthquake, there might be havoc and chaos in the society and individual which led to improve the approach by the doctors and health personal. With huge influx of people, there might be different questions and queries to the people, so health personal had improved their services to the mankind.

\section{Conclusion}

The study had explored the quality service of health institution at the time of diagnosis of health problem of patients. The study identified the answering the queries of patient, counselling of doctor, clearly explained about the problem by doctor, and approach of doctors. The statistical result of t-test shows that there was significant difference in approach of doctors $(\mathrm{p}=.012)$, and counselling of doctors $(\mathrm{p}=.043)$ but there was no difference in answering the queries promptly $(p=.187)$, and explanation given for aliment $(p=.180)$. The descriptive data shows the slight increase in level of satisfaction of patient after earthquake. Almost four years is passed of earthquake and Nepal Government has managed the basic service of health facilities and provided additional support from other non-governmental organization also which may support in improvement in quality services. Though, still health post established in rural setting have inadequate human resource basically doctors are not adequate so Government should provide the trained Doctor in rural areas also to increase the access of rural people in health services.

\section{References}

Al-Salaymeh, M. (2013). The Extent of Satisfaction of Beneficiaries with the Quality of Health Service . International Journal of Economics \& Management Sciences, 41-54.

Binns, C., \& Low, W. (2015). Nepal Disaster: A Public Health Response Needed. Asia Pac J Public Health, 27(5), 484-5.

Ministry of Health and Population. (2015). Health Sector Response: Earthquake 2015. Daily Situation Update Report. Kathmandu: Health Emergency.

Naghii, M. (2005). Public health impact and medical consequences of earthquakes. Pan Am J Public Health, 18(3), 216-21. 
Noji, E. (2000). The public health consequences of disasters. Prehosp disaster med, 15(4), 14757.

Partridge, R., Proano, L., Marcozzi, D., Garza, A., Nameth, I., \& Brinsfield, K. (2012). Oxford American Handbook of Disaster Medicine. Oxford University Press, 2012.

Petal, M. (2011). Earthquake Casualties Research and Public Education. In I. S. Spence R, Human Casualties in Earthquake. Springer: Netherlands.

Rocha Rodríguez MR, M. B. (2017). Level of satisfaction of the beneficiaries with the nursing care of a social security institution. Nursing \& Care Open Access Journal , 351-353.

Tembe, M., Dhakal, S., Shrestha, A., \& Mugele, J. (2018). Impact of Nepal Earthquake on Patients Presenting for Emergency Care at Patan Hospital. Disaster Medicine and Public Health Preparedness.

Watson, J., Gayer, M., \& Connolly, M. (2007). Epidemics after Natural Disasters. Emerg Infect Dis, 13(1), 1-5.

World Health Organization. (2016). Environmental health in emergencies: Vulnerable groups. Kathmandu: World Health Organization. 